\title{
Assessment of the impact of pesticide use in urban and periurban agriculture in Abidjan, Côte d'Ivoire
}

\author{
Perpétue MAMBE-ANI ${ }^{1 *}$, Koffi Nouho OUATTARA ${ }^{2}$, Fattoh Eric ELLEINGAND ${ }^{1}$ and \\ Vincent $\mathrm{KADJO}^{3}$ \\ ${ }^{1}$ Institut National Polytechnique Houphouët Boigny Yamoussoukro DFR-Génie Chimique et Agro-alimentaire, \\ BP 1013 Yamoussoukro, Côte d'Tvoire. \\ ${ }^{2}$ Université Nangui Abrogoua UFR Sciences et Gestion de l'Environnement, 02 BP 801 Abidjan 02, \\ Côte d'Ivoire. \\ ${ }^{3}$ Université Peleforo Gon Coulibaly UFR des Sciences Biologiques, BP 1328 Korhogo, Côte d'Ivoire. \\ "Corresponding author; E-mail: aniperptue@yahoo.fr
}

\begin{abstract}
Pesticides are used in agriculture for the control of pests and weedy species. Unfortunately, these chemicals are a potential risk for environment contamination and human toxicity. Market gardening soils are vulnerable to human activities because of the pesticide use. The objective of this work was to make a rapid and adequate diagnosis of the conditions of pesticide use by market gardeners. Thus, a view to assess the real impact of their use on the risk of soil pollution has been established. For this purpose, interviews and questionnaires were submitted to 243 market gardeners in Port-Bouët, Songon and Bingerville. 100\% of farmers use chemical pesticides on their farms. The most pesticides used are insecticides, fungicides and herbicides. $92 \%$ of farmers have a low education level and only $4.33 \%$ of them have received a good agricultural practices training. Unsafe practices such as fraudulent use of unregistered pesticides, noncompliance with recommended rates of pesticide, the use of cotton pesticides and persistent molecules have been observed. These practices increase the risk inherent of environment pollution and vegetables.
\end{abstract}

(C) 2019 International Formulae Group. All rights reserved

Keywords: Market gardening, pesticide, environment.

\section{INTRODUCTION}

Urban agriculture plays an important role in the economy of developing countries (Ba et al., 2016). It contributes significantly to poverty reduction through the many jobs and incomes generateds (Koffi-Nevry et al., 2011). This agriculture is highly vulnerable to pest leading to a high dependency of farmers on chemical pesticides (Wade, 2003; Hubert et al., 2014). Unfortunately, the toxicity of the molecules used is environmental issue (Mamy, 2008) and real problem for population health (Doumbia et al., 2009; Kouakou et al., 2016). In fact, pesticides can cause cancer, congenital malformations, endocrine, neurological and infertility problems, etc. (Kouakou et al., 2016).
Agriculture must ensure both a food security for the population and a preservation of healthy environment for future generations. Recently, Tano et al. (2012) studying production systems and high-risk practices in urban agriculture in Yamoussoukro, have highlighted the improper habits of mostly illiterate market gardeners. Another study reports scandalous and inappropriate agricultural practices that are not eco-friendly in Abidjan, Anyama and Dabou (Doumbia et al., 2009). Hence, it is necessary to update the current state of phytosanitary practices and the conditions of pesticide use by vegetable producers in Abidjan and suburbs. The aim of this study was to examine the practices of pesticide use; specifically to: i) list all active molecules used in vegetable gardening in the 
sites selected, ii) assess the conditions of their use, iii) identify the practices of farmers which may have an adverse effect on the environment and population health.

\section{MATERIALS AND METHODS Study site description}

The study was carried out in three areas of high vegetables production (PortBouët, Songon and Bingerville). Port-Bouët airport is located south-east of Abidjan between $5^{\circ} 20$ north latitude and $4^{\circ} 00$ west longitude. Songon-M'Brathé-agban-attié is located in west part of Abidjan between $5^{\circ} 19$ north latitude and $4^{\circ} 15$ west longitude while Bingerville, a suburb north of Abidjan is between $5^{\circ} 21$ north latitude and $3^{\circ} 54$ west longitude. Figure 1 shows the selected areas that are delineated in red in which red circles represent studied sites.

\section{Data collection}

A survey and interviews based on the work of Kadjo et al. (2016) were carried out with market gardeners and Ivorian farmers' supervisory structure ANADER (Agence Nationale d'Appui au Développement rural). ANADER permitted to select the different study areas. This study was conducted from August to October 2017 and from February to March 2018. The population was made up of growers who are field owners or permanent labours. Most of farmers were malinké, so we have used a translator during survey. The sampling procedure was snowball sampling. 243 market gardeners, including 90 in Songon, 74 in Port-Bouët and 79 in Bingerville were interviewed. Questionnaires focused on different types of pesticides used, frequencies of pesticide application, the use of personal protective equipment (PPE), the storage of pesticide and on the pre harvest interval. Information regarding social status of producers was also collected.

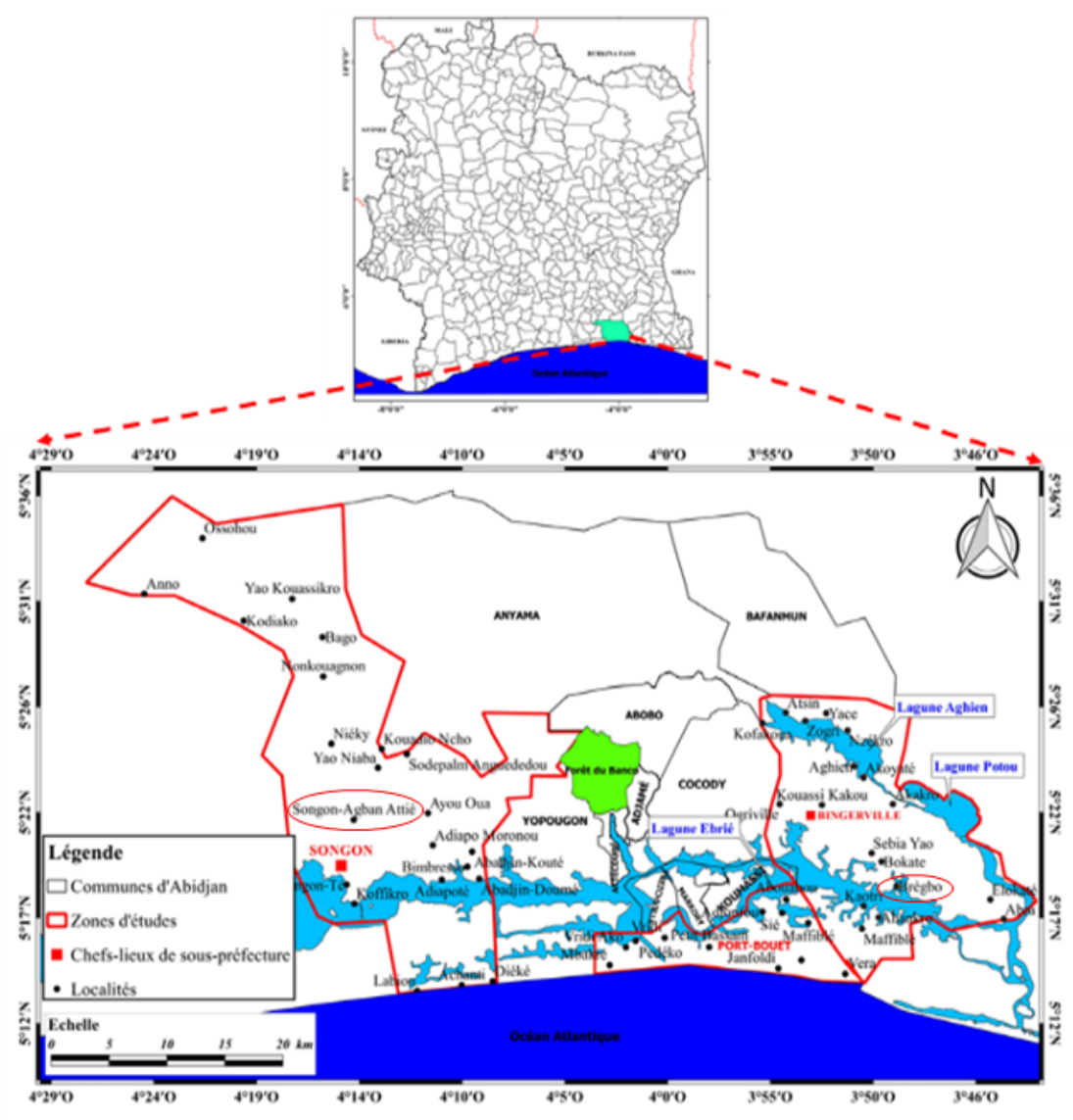

Figure 1: Map of study site. 


\section{RESULTS}

\section{Market gardeners characteristics}

Of the 243 farmers, 228 (94\%) were

men. The most representative age group was 31 to 45 years (Figure 2). The results showed a high level of illiteracy among the farmers $(92 \%)$. The highest level of education recorded was primary school. Only $4.33 \%$ of producers have received training on good agricultural practices. Half of the producers $(55.14 \%)$ interviewed have more than 10 years of activity and report using pesticides since they started market gardening. 28.80\% of the actors have between 5 and 10 years of agricultural activity, while $16.04 \%$ have less than 5 years of activity. Producers did not let the land lie fallow because of the great demand for vegetables. Several speculations are practised, including tomatoes, lettuce, pepper, cabbage, cucumber, leafy vegetables, eggplants, okra, leafy onion, carrots, turnips, parsley, mint, etc., with a specialization for each production area.

\section{Pesticide used}

All gardeners use chemical pesticides for crop protection. The most pesticides used was insecticides which represented $72.50 \%$ of the pesticides used, followed by fungicides $(17.70 \%)$ and herbicides which represented $9.80 \%$. The results are shown in Figures 3 and 4.

43 pesticides were regularly applyied in the fields (Table 1), many of them intended for the cotton culture. Cotton pesticides are used on the 3 study sites. Persistent active substances such as Bromacil and Diuron were used. Farmers also use prohibited molecules such as carbofuran. The use of unregistered pesticides such as Gramoquat 200 SL, Bravo and Super 360 SL were also reported. Moreover, farmers use pesticides such as "Bien-bien", "Feu-vert", "Solution", "karakoro", "Killer", "Machette", "Bôrô", "Krakon". These latter are not listed in the phytosanitary guidebook of Côte d'Ivoire (Danho et al., 2015). The majority of the pesticides used in the study sites belong to synthetic pyrethroid. All chemical groups and active ingredients of pesticides used in the different study sites are listed in Table1.

The results indicated that the most active ingredients used are glyphosate, cypermethrin and mancozeb. The most chemical groups represented in the study are pyrethroid, dithiocarbamate, organophosphorus and aminophosphonate. Figure 5 shows different chemical groups of pesticides used.

\section{Supply sources, storage, pesticide} spraying method and means of protection

The producers from Songon and Bingerville sites purchase pesticides from authorized distributors and local markets. However, producers at Port-Bouët airport have three sources of supply, these are authorised distributors, local markets and small retailers located on the production sites. After purchasing pesticides, the respondents store pesticides at home and on production sites. Knapsack sprayers are the only spraying equipment used for the application of pesticides. During spraying, producers do not use full personal protection equipment such as goggles, gloves, masks, suitable shoes or boots, coveralls, etc. They are partialy protected by using masks or nose protection only (67\%), while $33 \%$ do not use any protection at all.

Applied rates, management of remaining pesticide solution after application and frequency of crop treatment with chemical pesticides

The majority of vegetable producers have great difficulty to respect the prescribed doses because of the high illiteracy rate $(92 \%)$. After full application of the plot, the remaining pesticide solution is re-applied on the plot. The washing of equipment used for pesticide application (knapsack sprayers) is done in the farms and near the wells from which water was drawn for crops watering.

For the dame crop, the number of treatments differs from one farmer to another. All farmers treat the soil with pesticides especially nematicides before sowing. Crop treatments are generally carried out every 7 
days with insecticides. In the event of heavy attacks, producers use to treat the fields every week, but in the absence of pest attacks, crop treatments are still carried out. Treatments with insecticides and nematicides start before sowing and continue until the vegetables harvest. These latter were used 15 to 20 times depending on the speculation practiced. For tomatoes, cabbage and lettuce, the number of treatments with nematicides and insecticides was respectively 16,17 and 7 .

\section{Pre-harvest interval and management of empty pesticide containers}

The pre-harvest intervals of pesticide used were 3, 7, 15, 21 and 45 days (Figure 6). All growers recognized that they must respect the time between the last pesticide application and the harvest time. $47 \%$ of growers observe 7 days waiting period before harvest for all pesticides used, while $27 \%$ of them respect a time of 15 days, only $3 \%$ of producers apply 21 days waiting period and $20 \%$ have a 3 days waiting period. For instance, for active ingredient chlorpyriphos-ethyl with 45-day pre-harvest intervals, none of farmers observe this time limit.

As depicted in Figure 7, the majority of sampled growers namely $68.31 \%$ release empty pesticide containers into the environment and on the production site, $17.69 \%$ of them bury it and $14.00 \%$ incinerate it.

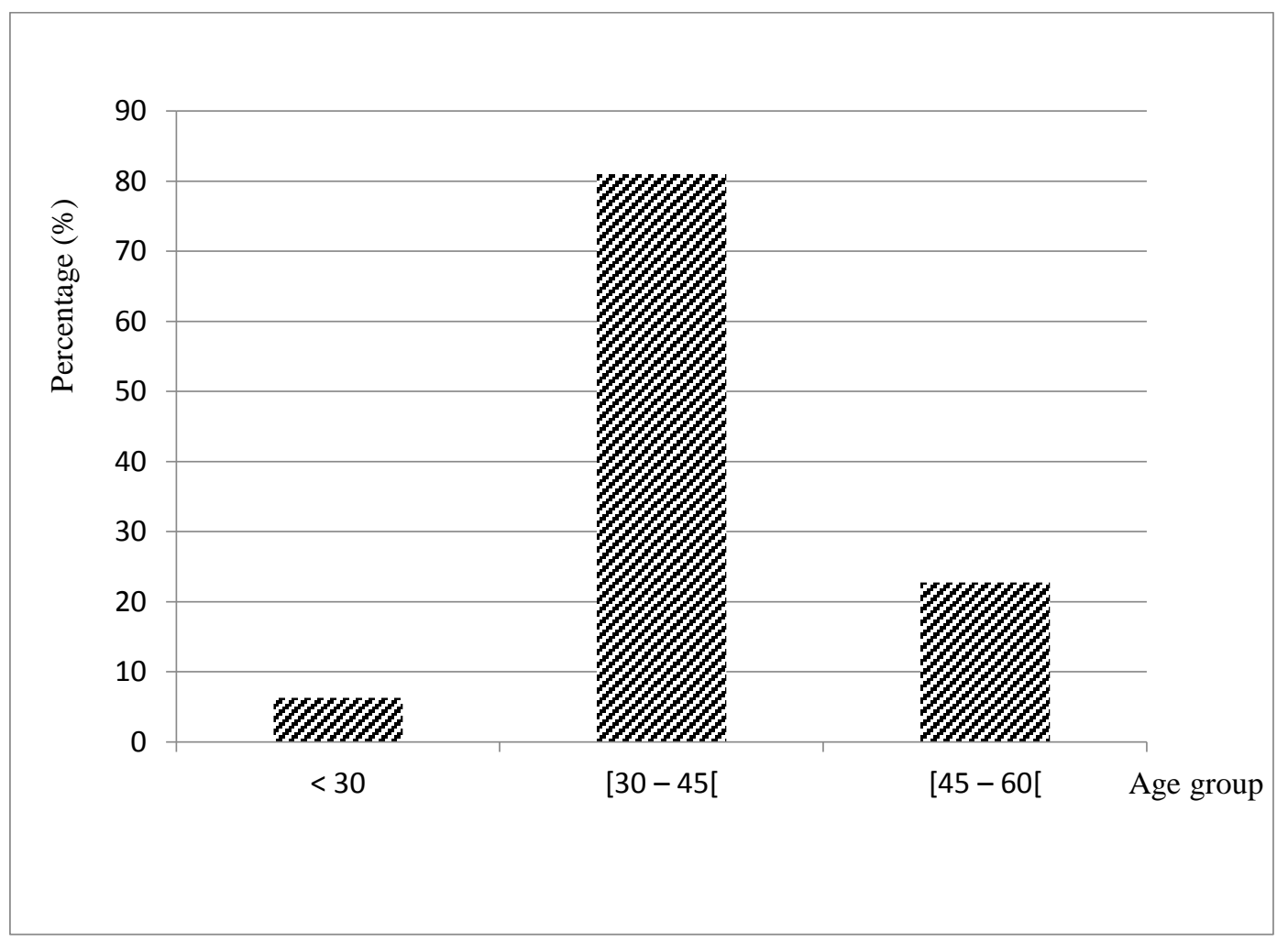

Figure 2 : Distribution of producers by age. 


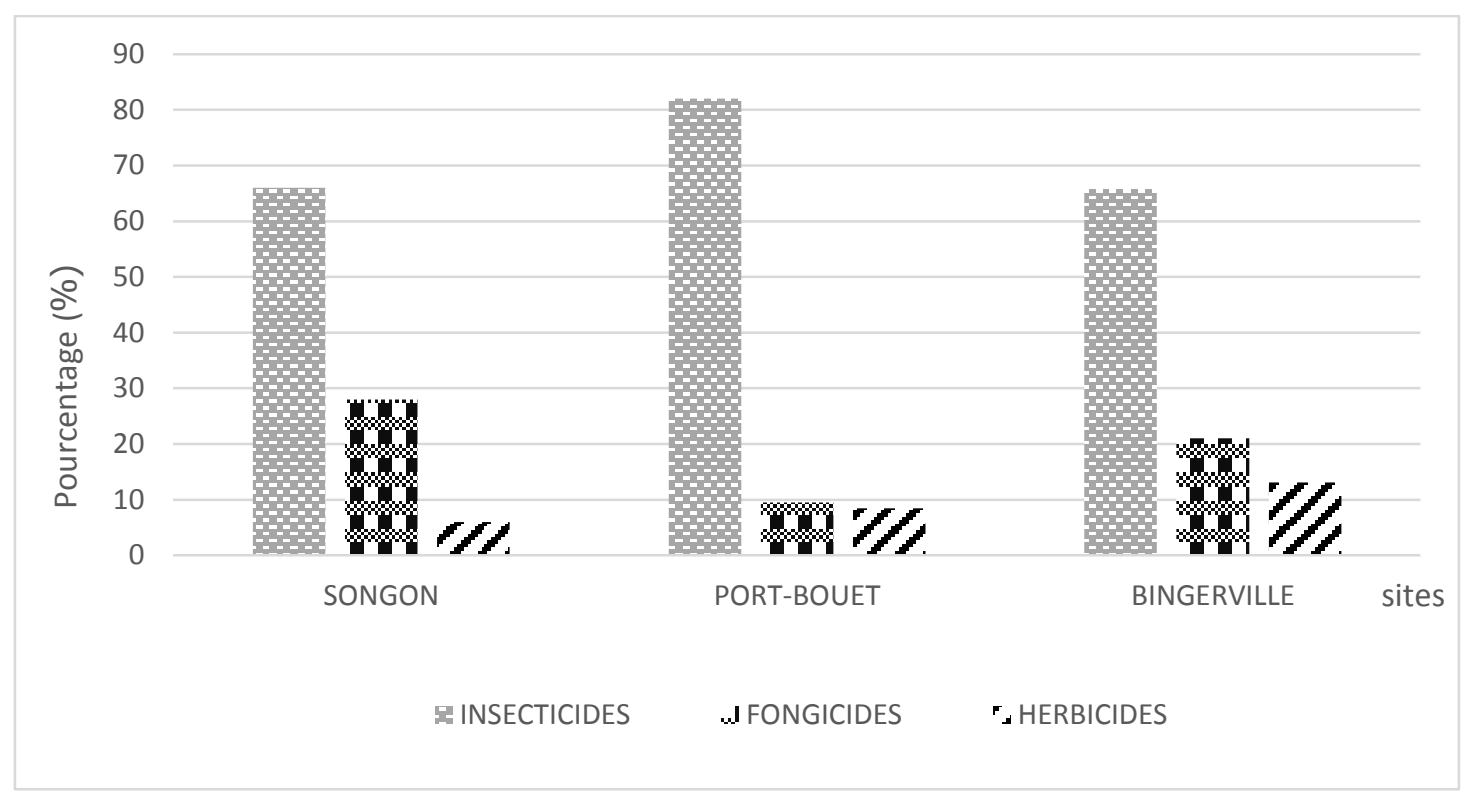

Figure 3: Distribution of pesticides used by study site.

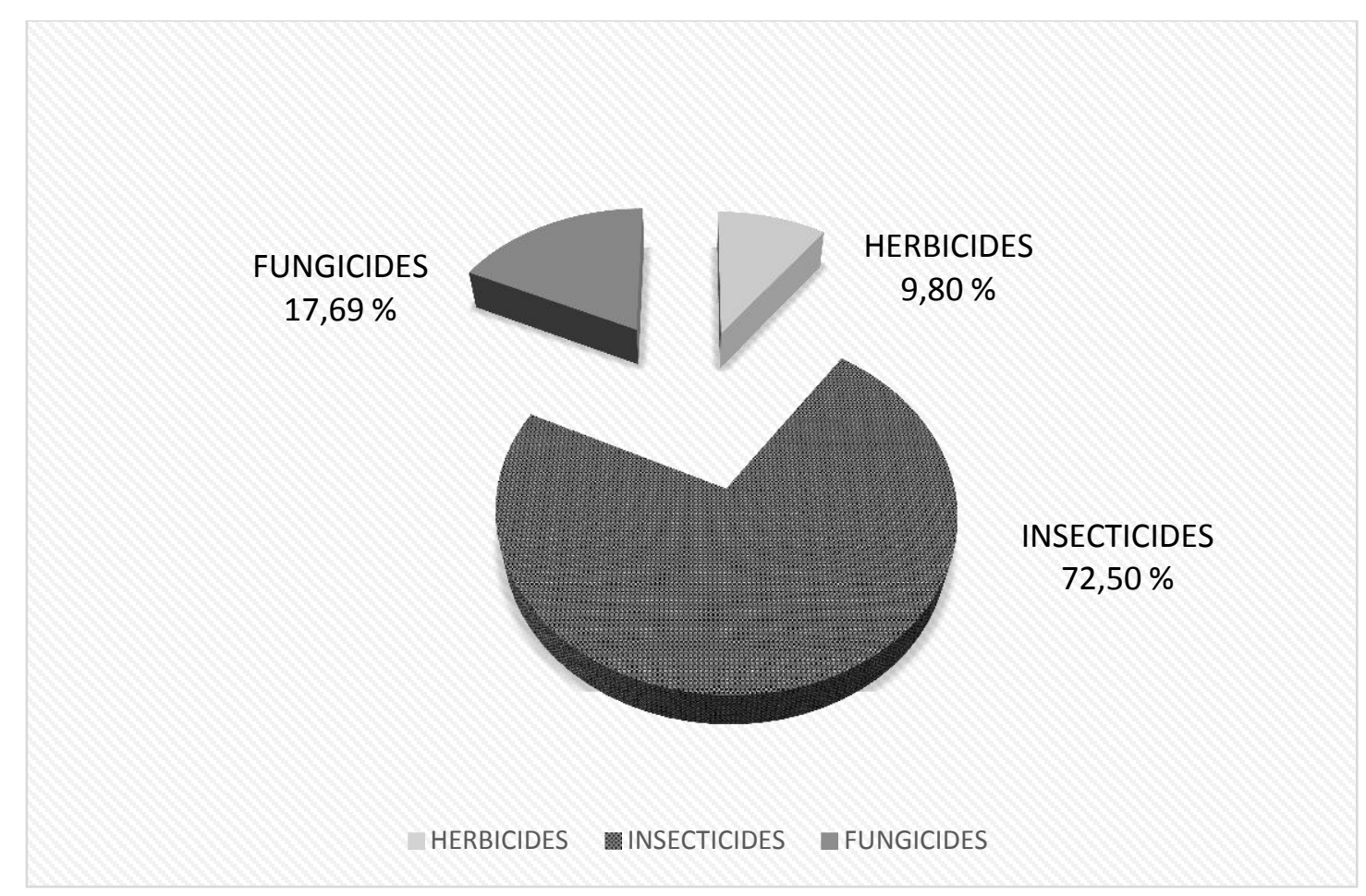

Figure 4: Proportion of various pesticides used by market gardeners. 
Table 1: List of pesticide used in the study areas.

\begin{tabular}{|c|c|c|c|c|}
\hline $\begin{array}{l}\text { Trading } \\
\text { Names }\end{array}$ & $\begin{array}{l}\text { Active } \\
\text { ingredients }\end{array}$ & Chemical group & Culture & $\begin{array}{l}\text { Fao/who } \\
\text { toxicological class }\end{array}$ \\
\hline \multicolumn{5}{|l|}{ INSECTICIDES } \\
\hline Calfos 500 EC & profenofos & organophosphate & cotton & II \\
\hline Cybog 50 EC & cypermethrin & pyrethrnoid & vegatable & II \\
\hline Cypercal 50 EC & cypermethrin & pyrethrnoid & $\begin{array}{l}\text { vegetable, } \\
\text { Food crop, } \\
\text { cotton }\end{array}$ & III \\
\hline Cypercal P 186 EC & $\begin{array}{l}\text { profenofos } \\
\text { cypermethrin }\end{array}$ & $\begin{array}{l}\text { Organophosphate } \\
\text { pyrethrnoid }\end{array}$ & cotton & III \\
\hline Cyperax 50 EC & cypermethrin & pyrethrnoid & vegetable & II \\
\hline Décis 12,5 EC & deltamethrin & pyrethrnoid & $\begin{array}{l}\text { Vegetable, } \\
\text { Food crop, } \\
\text { fruit }\end{array}$ & III \\
\hline Dragonforce $50 \mathrm{SC}$ & $\begin{array}{l}\text { lambda- } \\
\text { cyhalothrin } \\
\text { imidacloprid }\end{array}$ & $\begin{array}{l}\text { pyrethrnoid } \\
\text { neonicotinoid }\end{array}$ & cocoa & II \\
\hline Duel 186 EC & $\begin{array}{l}\text { cypermethrin } \\
\text { profenofos }\end{array}$ & $\begin{array}{l}\text { pyrethrnoid } \\
\text { organophosphate }\end{array}$ & cotton & II \\
\hline Furadan 10 GR & carbofuran & carbamate & pineapple & $\mathrm{Ib}$ \\
\hline Kart 500 SP & cartap & carbamate & $\begin{array}{l}\text { Banana, oil } \\
\text { palm }\end{array}$ & II \\
\hline K- optimal 35 EC & $\begin{array}{l}\text { lambda- } \\
\text { cyhalothrin- } \\
\text { acetamiprid }\end{array}$ & $\begin{array}{c}\text { pyrethrnoid } \\
\text { neonicotinoid }\end{array}$ & vegetable & II \\
\hline K- total & $\begin{array}{l}\text { lambda- } \\
\text { cyhalothrin- } \\
\text { acetamiprid }\end{array}$ & $\begin{array}{l}\text { Pyrethrnoid } \\
\text { neonicotinoid }\end{array}$ & vegetable & III \\
\hline Lamdac 46 EC & $\begin{array}{l}\text { lambda- } \\
\text { cyhalothrin } \\
\text { acetamiprid }\end{array}$ & $\begin{array}{l}\text { pyrethrnoid } \\
\text { neonicotinoid }\end{array}$ & cotton & II \\
\hline Lampfos 168 EC & $\begin{array}{l}\text { lambda } \\
\text { cyhalothrin } \\
\text { profenofos }\end{array}$ & $\begin{array}{l}\text { Pyrethrnoid } \\
\text { organophosphate }\end{array}$ & cotton & II \\
\hline Legumax 12 EC & deltamethrin & pyrethrnoid & vegetable & III \\
\hline Miracle 50 EC & $\begin{array}{l}\text { lambda } \\
\text { cyhalothrin }\end{array}$ & pyrethrnoid & vegetable & II \\
\hline Orthène $75 \%$ SP & acephate & organophosphate & vegetable & III \\
\hline Polythrine C 186 EC & $\begin{array}{l}\text { cypermethrin } \\
\text { profenofos }\end{array}$ & $\begin{array}{l}\text { Pyrethrnoid } \\
\text { organophosphate }\end{array}$ & cotton & III \\
\hline Pyrical 480 EC & $\begin{array}{l}\text { chlorpyriphos- } \\
\text { ethyl }\end{array}$ & organophosphate & pineapple & II \\
\hline Pyriforce 480 EC & $\begin{array}{l}\text { chlorpyriphos- } \\
\text { ethyl }\end{array}$ & organophosphate & pineapple & II \\
\hline $\begin{array}{l}\text { Tout maraîcher } 50 \\
\text { EC }\end{array}$ & cypermethrin & pyrethrnoid & vegetable & II \\
\hline
\end{tabular}




\begin{tabular}{|c|c|c|c|c|}
\hline $\begin{array}{l}\text { Trading } \\
\text { Names }\end{array}$ & $\begin{array}{l}\text { Active } \\
\text { Ingredients }\end{array}$ & $\begin{array}{l}\text { Chemical } \\
\text { Group }\end{array}$ & Culture & $\begin{array}{l}\text { Fao/who } \\
\text { toxicological class }\end{array}$ \\
\hline \multicolumn{5}{|c|}{ HERBICIDES } \\
\hline $\begin{array}{l}\text { Baratchè } \\
360 \text { SL }\end{array}$ & glyphosate & aminophosphonate & fallow & III \\
\hline $\begin{array}{l}\text { Bibana } 360 \\
\text { SL }\end{array}$ & glyphosate & aminophosphonate & fallow & III \\
\hline $\begin{array}{l}\text { Bravo super } \\
360 \text { SL }\end{array}$ & glyphosate & aminophosphonate & fallow & III \\
\hline $\begin{array}{l}\text { Curacron } \\
500 \mathrm{EC}\end{array}$ & profenofos & organophosphate & cotton & II \\
\hline Daba & $\begin{array}{l}\text { glyphosate potassium } \\
\text { salt }\end{array}$ & aminophosphonate & fallow & III \\
\hline $\begin{array}{l}\text { Dragonflash } \\
720 \mathrm{SL}\end{array}$ & 2, 4-D amine salt & aryloxy-acetic acid & cereal & III \\
\hline $\begin{array}{l}\text { Glyphader } \\
360 \text { SL }\end{array}$ & glyphosate & aminophosphonate & fallow & III \\
\hline $\begin{array}{l}\text { Gramoquat } \\
200 \mathrm{SL}\end{array}$ & glyphosate & aminophosphonate & fallow & III \\
\hline $\begin{array}{l}\text { Herbextra } \\
720 \mathrm{SL}\end{array}$ & 2,4- D amine salt & aryloxy-acetic acid & rice & II \\
\hline $\begin{array}{l}\text { Herbigro } \\
720 \mathrm{SL}\end{array}$ & 2.4-D amine salt & aryloxy-acetic acid & cereal & II \\
\hline $\begin{array}{l}\text { Ikokadigne } \\
108 \mathrm{EC}\end{array}$ & haloxyfop-R-methyl & $\begin{array}{l}\text { arloxyphénoxypropi } \\
\text { onate }\end{array}$ & $\begin{array}{l}\text { Cotton } \\
\text { vegetable }\end{array}$ & III \\
\hline $\begin{array}{l}\text { Kalach } 360 \\
\text { SL }\end{array}$ & glyphosate & aminophosphonate & & III \\
\hline $\begin{array}{l}\text { Ladaba } 480 \\
\text { SL }\end{array}$ & glyphosate & aminophosphonate & $\begin{array}{l}\text { Hevea, oil palm, } \\
\text { banana, Fallow }\end{array}$ & III \\
\hline $\begin{array}{l}\text { Rangro } 360 \\
\text { SL }\end{array}$ & glyphosate & aminophosphonate & fallow & III \\
\hline $\begin{array}{l}\text { Round up } \\
360 \mathrm{SL}\end{array}$ & glyphosate & aminophosphonate & All fallow crops & III \\
\hline $\begin{array}{l}\text { Super } 30 \\
\text { WP }\end{array}$ & $\begin{array}{l}\text { bromacil } \\
\text { diuron }\end{array}$ & $\begin{array}{l}\text { uracil } \\
\text { urea }\end{array}$ & Pineapple & III \\
\hline
\end{tabular}

II: moderately dangerous; III: slightly dangerous; Ib: Highly dangerous 


\begin{tabular}{|c|c|c|c|c|}
\hline $\begin{array}{l}\text { TRADING } \\
\text { NAMES }\end{array}$ & $\begin{array}{l}\text { ACTIVE } \\
\text { INGREDIENTS }\end{array}$ & $\begin{array}{l}\text { CHEMICAL } \\
\text { GROUP }\end{array}$ & CULTURE & $\begin{array}{l}\text { FAO/WHO } \\
\text { TOXICOLOGICAL } \\
\text { CLASS }\end{array}$ \\
\hline \multicolumn{5}{|l|}{ FUNGICIDE } \\
\hline $\begin{array}{l}\text { Banko PLUS } 650 \\
\text { SC }\end{array}$ & $\begin{array}{l}\text { chlorothalonin } \\
\text { carbendazim }\end{array}$ & $\begin{array}{l}\text { chloronitrile } \\
\text { benzimidazole } \\
\text { carbamate }\end{array}$ & vegetable & III \\
\hline Ivory $80 \% \mathrm{WP}$ & mancozeb & dithiocarbamate & vegetable & III \\
\hline Monjardin $80 \mathrm{WP}$ & mancozeb & dithiocarbamate & vegetable & III \\
\hline Ortiva $250 \mathrm{SC}$ & strobilurin & azoxystrobin & mango & III \\
\hline Qualico $46 \% \mathrm{WP}$ & $\begin{array}{l}\text { dimetomorph } \\
\text { copper oxychloride }\end{array}$ & cinnamic acid & cocoa & III \\
\hline Zebra $800 \mathrm{WP}$ & mancozeb & dithiocarbamate & vegetable & III \\
\hline
\end{tabular}

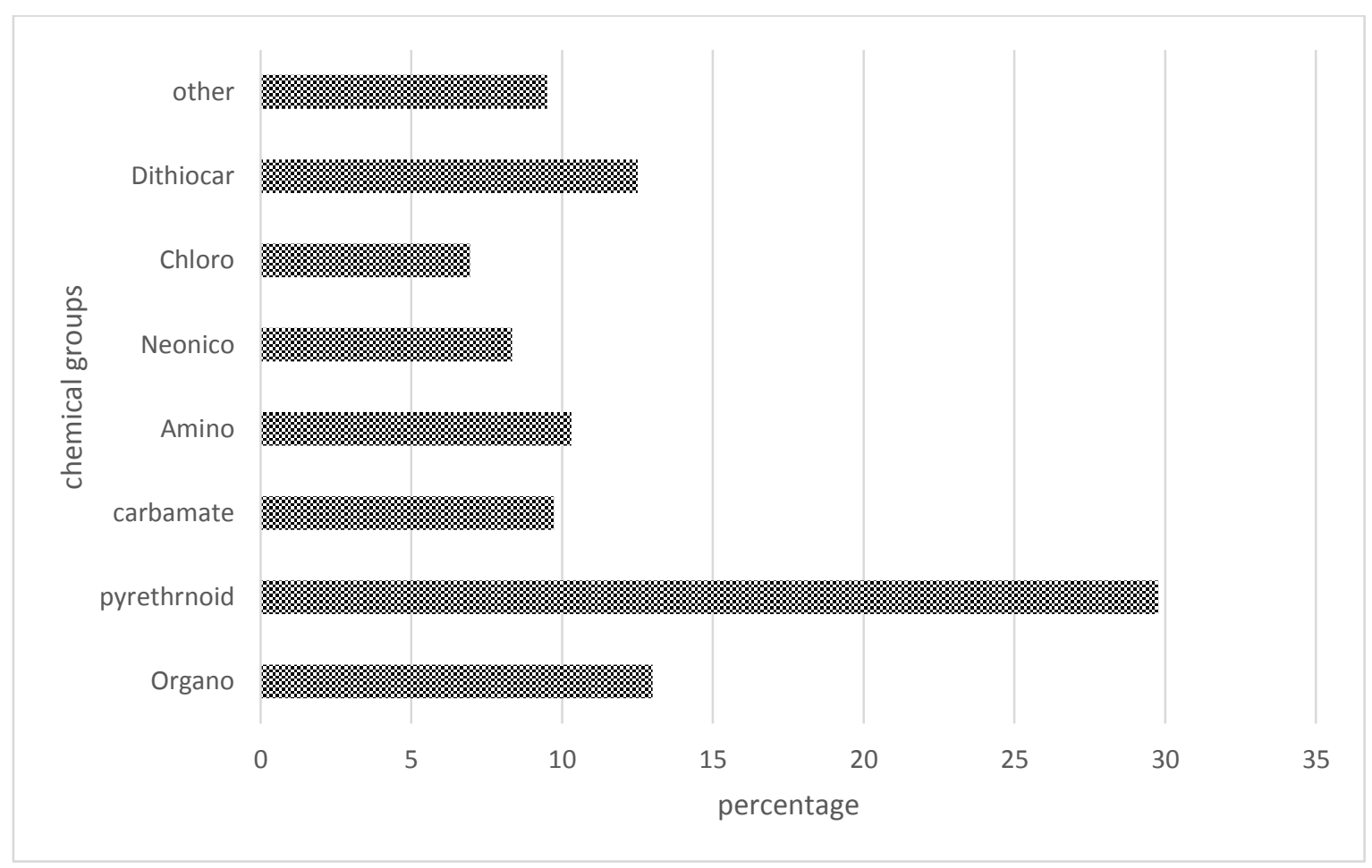

Figure 5: chemical groups of pesticides used by producers.

Organo $=$ organophosphate pyrethrnoid $=$ pyrethrnoid carbamate $=$ carbamate $;$ amino $=$ aminophosphonate Neonic $=$ neonicotinoid; dithiocar $=$ dithiocarbamate chloro $=$ chloronitrile 


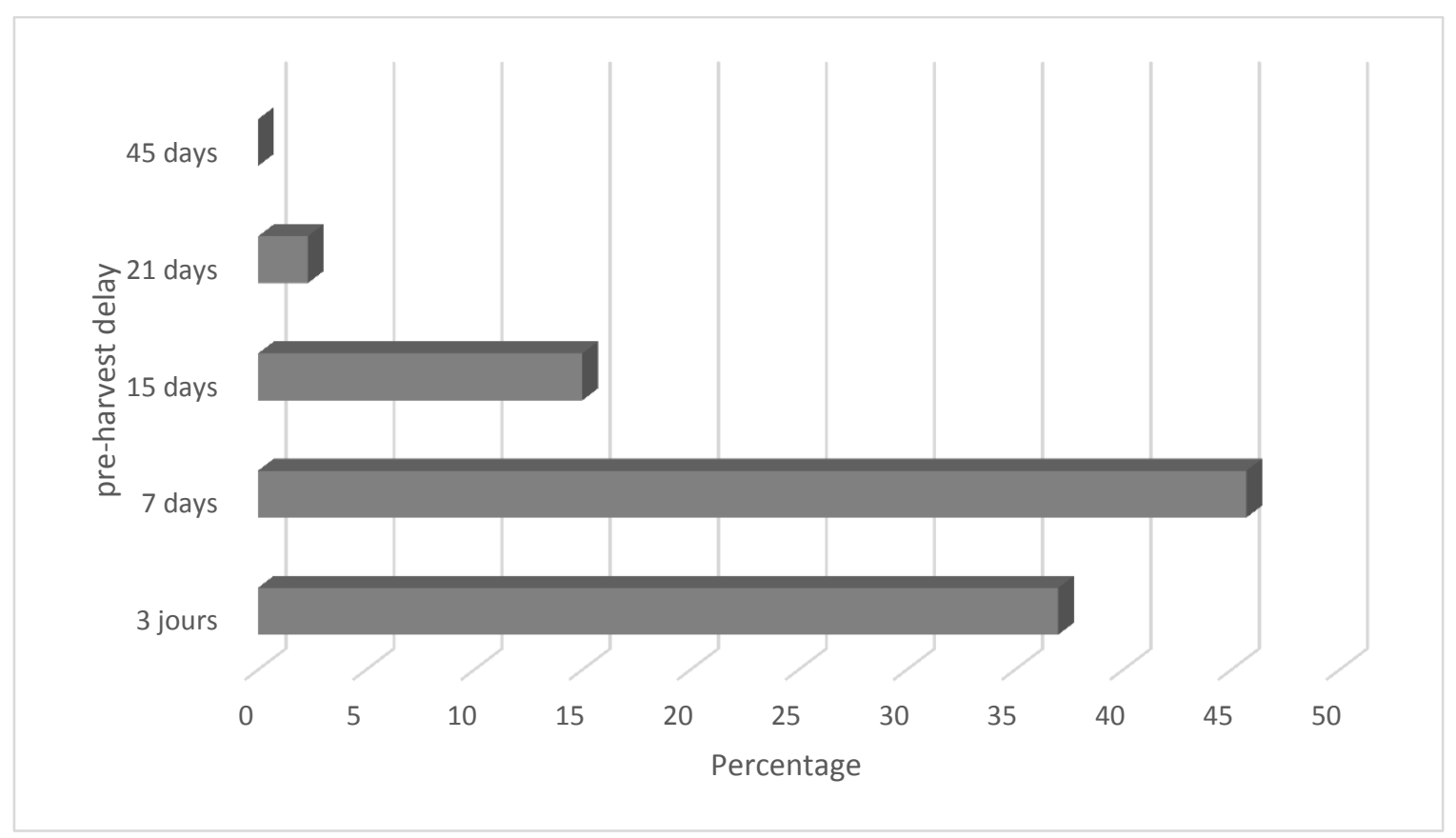

Figure 6: Proportion of farmers according to respect of different pre-harvest intervals.

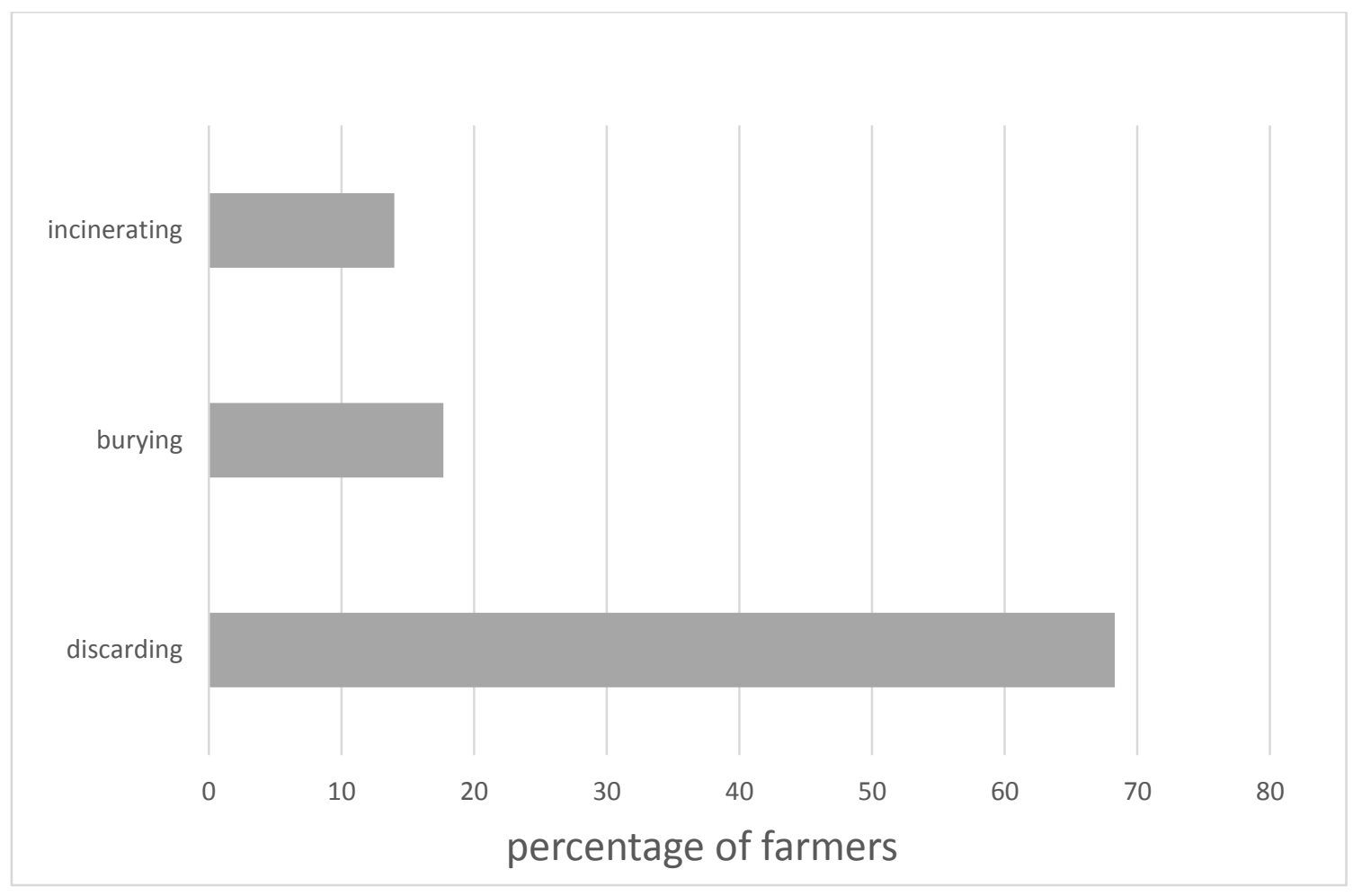

Figure 7: Distribution of producers according to the management of empty pesticide containers. 


\section{DISCUSSION}

\section{Characteristics of the vegetable growers}

This study showed that the actors involved in agriculture in Abidjan and its suburb were predominantly men $(94 \%)$. The results obtained in this study are in agreement with those of Tano et al. (2012) done in Yamoussoukro. These authors observed a high proportion $(88 \%)$ of men in urban agriculture. This can be explained by the fact that men have more financial capacity to buy or rent a land than women. The low representation of women $(6 \%)$ in this activity could be justified by the fact that women's investment choice depends on the prior agreement of men (Séry, 2012).

The survey results showed the presence of all age groups. Market gardening is dominated by individuals aged 31 to 45 years $(79.01 \%)$. This tendency may be due to the unployment of this age group resulting from rural exodus, forcing them to fall back on market gardening. That was also demonstrated in other studies conducted by (Matthys et al., 2006; Kanda et al., 2009; Ducroquet et al., 2017). In our study, the proportion of young farmers $(79.01 \%)$ was higher than that found by Bayendi et al. (2017) and Le Bellec et al. (2017) in Gabon and Mauritanie, who reported an aging of vegetable growers of $63 \%$ and $60 \%$ respectively. The financial profitability of market gardening would also explain young people's interest in this sector of activity. The low rate of vegetable producers over 45 years of age in this sector can be explained by the difficulty of this activity. It must be noted that market gardening requires physical constraints such as long working hours, huge physical tasks such as weeding and harvesting.

The low education level amongst the producers $(92 \%)$ constitutes a real constraint for the development of this activity. This situation leads to the inability of vegetable growers to read the instructions on the pesticide packagings and increases the risk of misuse of pesticides, which may contribute to the pollution of the soil. Previous works carried out by Ngom et al. (2012), Wognin et al. (2013), Diop (2013); Naré et al. (2015) and Dao et al. (2016) corroborated our results namely (92\%). These authors diagnosed a low education level among producers which leads to an irrational use of pesticides and therefore to the contamination of vegetables. These observations are corroborated by the work of Ahouangninou et al. (2011) in Benin, who observed that producers did not apply the dosages indicated on packagings because of their difficulty in reading the instructions for use and carrying out a precise dosage.

\section{Environmental and health risks of pesticide} use

The sampled farmers (100\%) use pesticides on their farms. The most pesticide used was insecticide $(72.50 \%)$. Our results confirm those of Kanda et al. (2009), Doumbia et al. (2009) and Tano et al. (2012) who have studied the cultivation practices of vegetable producers. These authors showed the highest level of insecticide use in Togo (78.1\%), in Abidjan (78.57\%) and in Yamoussoukro (73\%). In another study in Benin, conducted by Ahouangninou (2011) with the same aim presented different results. This author has shown the highest level of fungicide use $(68 \%)$.

Generally, under normal conditions of use, pesticide do not present neither a health nor environmental hazard. The presence of pesticide residues in soils and vegetables is associated with the misuse and overuse of pesticide (Botwe et al., 2011). Various practices such as the use of unregistered pesticides and toxic active ingredients were observed in this study. This situation leads to increase the risks of environmental pollution 
that was described by Ahouangninou et al. (2012) and Kanda et al. (2014). These authors showed the impact of pesticide misuse on aquatic organisms and soil invertebrates, contributing to soil depletion. The use of toxic molecules such as Carbofuran, which is class Ib (highly dangerous) and the use of cotton pesticides in our study are a major hazard to consumers and soil environment. Similar studies conducted by Doumbia et al. (2009); Soulé et al. (2010) and Son et al. (2018) indicated that the pesticide use contribute to environmental pollution, that is a real health risk for vegetables, soil, groundwater and air.

Concerning the organochlorine pesticides, our investigations showed that no farmers use them, which suggests that farmers are aware of the danger of organochlorine pesticides use. However, the present results are in contradiction with those of Tano et al. (2012) and Ba et al. (2016) who reported the use of organochlorine pesticides in market gardening. Our results are in line with those of Agnandji et al. (2018) in Benin. Results of this study point to unsafe practices such as excessive pesticide use, non-compliance with recommended rates of pesticide and repeated pesticide use (reapplication of pesticide and on crops), these practices lead to potential exposures to pesticide residues in vegetables and soils. In other studies conducted by Biego et al. (2009), Naré et al. (2015) and Son et al. (2018) with the aim to assess the attitude and practices of farmers pointed to the pesticide misuse, which was a real risk of vegetables and soils contamination. Non-compliance with pre-harvest intervals observed in our study, increases the presence pesticide residues in vegetables.

Concerning the management of empty pesticide containers (incinerating, discarding, burying) by farmers, the sampled farmers adopted unsafe and not eco-friendly practices, which increases the risk of environmental pollution, similar results have been reported by Tarnagda et al. (2017) in Burkina Faso.

\section{Conclusion}

The study on the current situation of pesticide use in Abidjan and its suburban showed that all producers use pesticides on their gardens. The majority of vegetable growers have a low education level and 10 years of agricultural activity. The study reveals the use of many cotton pesticides. The use of unregistered pesticides, banned and persistent molecules have been identified. All these practices lead to the presence of pesticide residues in the environment, which exposes the population to many illnesses. This study highlighted the unsafe practices of producers that expose consumers and the environment. Thus, contamination of the environment by chemical pesticides with proven toxicity exposes the entire ecosystem. It is therefore recommended training programs on the farms for the safe use of pesticide. Given that the results of this study are based on the responses of market gardeners and on observations on-farm, further analysis of the residues of pesticide listed in this study is necessary in order to know the actual real state of pollution of market gardening soils.

\section{COMPETING INTERESTS}

The authors state that there is no competing interest between them.

\section{AUTHORS' CONTRIBUTIONS}

The four (4) authors MAP, ONK, EFE and $\mathrm{KV}$ together carried out this work. The survey data were collected by MAP. ONK, EFE and KV supervised, read, commented, made corrections and approved the final document. 


\section{ACKNOWLEDGEMENTS}

Above all, we would like to thank all the actors in the market gardening sector, in particular the market gardeners who, by agreeing to participate in the survey, contributed to the production of this article. We also thank the presidents of the vegetable production cooperatives in the localities surveyed. We also thank the farmers' supervisory structure, namely ANADER (Agence Nationale d'Appui au Développement rural).

\section{REFERENCES}

Agnandji $\mathrm{P}$, Cachon $\mathrm{BF}$, Ménonvè $\mathrm{A}$, Mawussi ASI, Sanni A, Fanou AL. 2018. Analyse des pratiques phytosanitaires en maraîchage dans les zones intra-urbaines (Cotonou) et péri-urbaines (Sèmèkpodji) au Sud-Bénin. Rev. Afr. Env. Agric., 1(1): 2-11. URL: http://www.researchgate.net/publication/ 329161588

Ahouangninou C, Fayomi BE, Martin T. 2011. Évaluation des risques sanitaires et environnementaux des pratiques phytosanitaires des producteurs maraîchers dans la commune rurale de Tori-Bossito (Sud-Bénin). Cah. Agric., 20(3) : 216-222. DOI: 10.1684/agr.2011.0485.

Ahouangninou C, Martin T, Edorh P, Bangana BS, Onil S, Louis SL, Dion S, Fayomi B. 2012. Characterization of Health and Environmental Risks of Pesticide Use in Market-Gardening in the Rural City of Tori-Bossito in Benin, West Africa. J. Environ. Prot., 3: 241248. DOI:10.4236/jep.2012.33030

Ba A, Cantoreggi N, Simos J, Duchemin E. 2016. Impacts sur la santé des pratiques des agriculteurs urbains à Dakar (Sénégal). VertigO, 16(1) : 1-14. DOI: 10.4000/vertigo. 17030
Bayendi LSM, Ndong NA, Francis F. 2017. Le maraîchage périurbain à Libreville et Owendo (Gabon) : pratiques culturales et durabilité. Cah. Agric., 26(4): 45002. DOI : $10.1051 /$ cagri/2017026

Biego GH, Coulibaly A, Koffi KM, Kouamé OC, Kouadio LP. 2009. Niveaux de résidus de pesticides organochlorés dans les produits du cacao en Côte d'Ivoire. Int. J. Biol. Chem. Sci., 3(2): 297-303. DOI: 10.4314/ijbcs.v3i2.44509

Botwe BO, Ntow WJ, Kelderman P, Drechsel P, Carboo D, Nartey VK, Gijzen HJ. 2011. Pesticide residues contamination of vegetables and their public health implications in Ghana. J. Environ. I. Agri. Dev. Count., 3(2): 10-18. http://www.academia.edu/26691985

Danho M, Abo K, Touré A, Kra KD, Akamou F, Bah B, Kouakou NJ, Kouamé KF. 2015. Index phytosanitaire. Ministère de l'agriculture et du développement rural (MINADER). République de Côte d'Ivoire.

Dao MCE, Sanou J, Pare S. 2016. Maraîchage urbain et semi-urbain de Moringa oleifera Lam. par des associations de femmes au Burkina Faso : contraintes et opportunités. VertigO, 16(1): 20-38. DOI : $10.4000 /$ vertigO. 17225

Diop A. 2013. Diagnostic des pratiques d'utilisation et quantification des pesticides dans la zone des Niayes de Dakar (Sénégal). Thèse de doctorat. Université du Littoral Côte d'Opale, France, p.241.

Doumbia M, Kwadjo KE. 2009. Pratiques d'utilisation et de gestion des pesticides par les maraîchers en Côte d'Ivoire : Cas de la ville d'Abidjan et deux de ses banlieues (Dabou et Anyama). J. Appl. Biosci., 18: $992 \quad-\quad 1002$. http//www.biosciences.elewa.org 
Ducroquet H, Tillie P, Louhichi K, Gomez-YPaloma S. 2017. L'agriculture de la Côte d'Ivoire à la loupe: Etat des lieux des filières de production végétales et animales. Publications Office of the European Union : Luxembourg.

Hubert DB, Huat J, Parrot L, Sinzogan A, Martin T, Malézieux E, Vayssières JF. 2014. Pesticide risks from fruit and vegetable pest management by small farmers in sub-Saharan Africa. A review. Agron. Sust. Dev., 34(4): 723-736. DOI: 10.1007/s13593-014-0216-7

Kadjo V, Etchian OA, Ble MC, Soro D, Yapi JN, Otchoumou A. 2016. Caractérisation de la pêche aux crevettes d'eau douce Atya scabra (Leach, 1815) (Decapoda: Atyidae) dans la rivière Bia, Côte d'Ivoire. Int. J. Biol. Chem. Sci., 10(2): 620-631. DOI: 10.4314/ijbcs.v10i2.14

Kanda M, Wala K, Batawila K, DjaneyeBoundjou G, Ahanchede A, Akpagana K. 2009. Le maraîchage périurbain à Lomé : pratiques culturales, risques sanitaires et dynamiques spatiales. Cah. Agric., 18(4): $356-363 . \quad$ DOI: 10.1684/agr.2009.0319

Kanda M, Apkavi S, Wala K, DjaneyeBoundjou G, Akpagana K. 2014. Diversité des espèces cultivées et contraintes à la production en agriculture maraîchère au Togo. Int. J. Biol. Chem. Sci., $\quad \mathbf{8}(1)$ : 115-127. $\quad$ DOI: 10.4314/ijbcs.v8i1.11

Koffi-Nevry R, Assi-Clair BJ, Koussemon M, Wognin AS, Coulibaly N. 2011. Potential enterobacteria risk factors associated with contamination of lettuce (Lactuca sativa) grown in the peri-urban area of Abidjan (Côte d'Ivoire). Int. J. Biol. Chem. Sci., 5(1): 279-290. DOI: 10.4314/ijbcs.v5i1.68104

Kouakou AS, Coulibaly SL, Coulibaly L, Savane I. 2016. Evolution Temporelle de l'utilisation des pesticides en agriculture tropicale dans le bassin versant de la Marahoué, Côte d'Ivoire. Int. J. Innov. App. Stud., 14(1): 121-131. URL: http://www.ijias.issr-journals.org

Le Bellec F, Scorbiac M, Sauzier J. 2017. Les pratiques phytosanitaires des producteurs de légumes de l'île Maurice : impacts et perspectives de changement. Cah. Agric., 26(5): 55001. DOI : $10.1051 /$ cagri/2017038

Mamy L, Barriuso E, Gabrielle B. 2008. Evaluer les risques environnementaux des pesticides: exemple du désherbage des cultures résistantes ou non au glyphosate. Innovations agronomiques, 3 : 121-143. https://www.inra.fr/ciag

Matthys B, Adiko AF, Cissé G. 2006. Le réseau social des maraîchers à Abidjan agit sur la perception des préoccupations et des risques sanitaires liés à l'eau. VertigO, 3(8): 1-11. DOI: 10.4000/vertigo. 1857

Naré RWA, Savadogo PW, Gnankambary Z, Nacro HB, Sedogo MP. 2015. Analyzing Risks Related to the Use of Pesticides in Vegetable Gardens in Burkina Faso. Agr. For. Fish., 4(4): 165-172. DOI: 10.11648/j.aff.20150404.13

Ngom S, Seydou T, Thiam MB, Anasthasie M. 2012. Contamination des produits agricoles et de la nappe phréatique par les pesticides dans la zone des Niayes au Sénégal. Rev. Sci. Technol., 25: 119-130. https://www.ajol.info/index.php/srst/artic le/view/117245

Séry A. 2012. Le microcrédit: l'empowerment des femmes ivoiriennes. Thèse de doctorat, Université Paul-ValeryMontpellier III, Montpellier, p. 382.

Son D, Zerbo F, Bonzi S, Legreve A, Somda I, Schiffers B. 2018. Assessment of Tomato (Solanum lycopersicum L.) Producers' Exposure Level to Pesticides, 
in Kouka and Toussiana (Burkina Faso).

Int. J. Environ. Res. Public Health,

15(2): 204.2 DOI:

10.3390/ijerph15020204

Soulé A, Edorh AP, Totin H, Koumolou L, Amoussou E, Aklikokou K, Boko M. 2010. Pesticides et métaux lourds dans l'eau de boisson, les sols et les sédiments de la ceinture cotonnière de Gogounou, Kandi et Banikoara (Benin). Int. J. Biol. Chem. Sci., 4(4): 1170-1179. DOI: 10.4314/ijbcs.v4i4.63054

Tano B, Abo K, Dembélé A, Fondio L. 2012. Systèmes de production et pratiques à risque en agriculture urbaine: cas du maraîchage dans la ville de Yamoussoukro. Int. J. Biol. Chem. Sci., 5(6): 2317-2329.

DOI:10.4314/ijbcs.v5i6.12

Tarnagda B, Tankoano A, Tapsoba F, Sourabié PB, Abdoullahi HO, Djbrine
AO, Drabo KM, Traoré Y, Savadogo A. 2017. Évaluation des pratiques agricoles des légumes feuilles : le cas des utilisations des pesticides et des intrants chimiques sur les sites maraîchers de Ouagadougou, Burkina Faso. J. Appl. Biosci., 117: 11658-11668. DOI: 10.4314/jab.v117i1.3

Wade CS. 2003. L'utilisation des pesticides dans l'agriculture périurbaine et son impact sur l'environnement. Thèse de doctorat en pharmacie. Université Cheickh Anta Diop, Dakar, p. 59.

Wognin AS, Ouffoue KS, Assemand EF, Tano K, Koffi-Nevry R. 2013. Perception des risques sanitaires dans le maraîchage à Abidjan, Côte d'Ivoire. Int. J. Biol. Chem. Sci., 7(5): 1829-1837. DOI: $10.4314 /$ ijbcs.v7i5.4. 